\title{
A rationale for effective post-fire debris flow mitigation within forested terrain
}

\author{
Jerome V. De Graff(D
}

\begin{abstract}
Watersheds recently burned by wildfires are recognized as having an increased susceptibility to debris flow occurrence. The great majority occur within the first 2 years following wildfires. These debris flows are generated primarily through the process of progressive entrainment of material eroded from hillslopes and channels by surface runoff and appears independent of the vegetative community burned. The decreased likelihood of debris flows over time is linked to the restoration of hydrologic function as vegetative cover and soil infiltration functioning return to pre-fire conditions. An exception to this pattern of post-wildfire debris flow susceptibility occurs in burned drainage basins with forest cover. A second, later period of increased debris flow susceptibility due to infiltration-triggered landslides can occur in burned forested basins. This later period of debris flow susceptibility is largely attributable to the fire-induced tree mortality and subsequent decay of tree root networks decreasing soil strength on steep hillslopes which produces an increased likelihood of debris flow occurrence 3 to 10 or more years after the wildfire. Consequently, post-fire mitigation measures in forested terrain must address the risk posed by debris flows caused by progressive entrainment during the 2 years following the wildfire and debris flows due to infiltration-induced debris slides three or more years later. Mitigation for the later debris flows in forested terrain involves identification of areas with infiltration-induced debris slides coincident with concentrations of fire-killed trees. Timely reforestation of these areas after a wildfire limits the loss of soil strength from decaying roots.
\end{abstract}

Keywords: Emergency response, Debris flows, Timing, Wildfire, Tree roots

\section{Introduction}

\section{Post-fire debris-flow hazard potential}

Where wildfires affect a vegetative community on steep slopes, a potential exists for post-wildfire debris flows to occur. The increased likelihood of debris flow occurrence from recently burned watersheds is a relatively recent addition to our understanding of post-fire effects and necessitates evaluation of the threat posed to nearby populations, property, and infrastructure (Cannon and Reneau, 2000; Cannon, 2001; Cannon et al., 2001). Debris flows pose a serious threat because they move rapidly, travel significant distances from their point of origin, and exert destructive force along their flow path and within their area of deposition (Hungr, 2005; Giraud and McDonald, 2007; Jordan and Covert, 2009) Post-wildfire debris flows clearly pose a hazard when burned watersheds are adjacent to populated areas

Correspondence: jdegraff@csufresno.edu

Department of Earth \& Environmental Science, California State University, Fresno, CA, USA

(c) The Author(s). 2018 Open Access This article is distributed under the terms of the Creative Commons Attribution 4.0 International License (http://creativecommons.org/licenses/by/4.0/), which permits unrestricted use, distribution, and reproduction in any medium, provided you give appropriate credit to the original author(s) and the source, provide a link to the Creative Commons license, and indicate if changes were made.
(Cannon and DeGraff, 2009) and can even be a hazard in a less populated rural settings (DeGraff et al., 2011). Consequently, post-fire evaluation needs tools to effectively identify, within a burned area, those drainage basins having a greater likelihood of generating debris flows in order to undertake timely and effective mitigation (DeGraff et al. 2007; Cannon et al. 2011; DeGraff et al., 2013; DeGraff, 2014; Staley et al., 2017).

The western United States has experienced an increase in wildfire activity including very large fires since the mid-1980s (Westerling et al., 2006, Barbero et al., 2015; Westerling, 2016). Like change in any natural system, the increase is attributable to multiple factors (Cannon and DeGraff, 2009; Abatzaglou and Williams, 2016). Climatic change in an important factor as reflected by the results of multiple studies using different time scales, spatial scales, fire metrics, or fire proxies (see Table 1, Barbero et al., 2015). Past fire suppression efforts are more clearly a factor influencing increased wildfire activity in forested areas (Parsons and DeBenedetti, 1979) than in

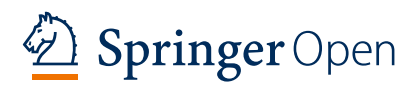


brushlands (Keeley and Fotheringham, 2001). The role of expanding regional population centers as represented by the wildland-urban interface is also significant for its influence on wildfire initiation and greater impact to communities (Keeley and Fotheringham, 2001; Radeloff et al., 2005).

The urgency associated with instituting measures to mitigate the adverse effects of debris flow depends on how soon they might occur after the fire. The timing is largely dependent on the time of initiating precipitation relative to the fire's occurrence. A variety of precipitation events including intense rainfall on melting snow (Meyer et al., 2001), rapid snowmelt (Schultz et al., 2006), prolonged winter and summer frontal storms (Cannon et al., 2008), cells of high-intensity rainfall within frontal storms (Cannon et al., 2011; Rengers et al., 2016), and summer convective storms (Wagner et al., 2013) have initiated post-fire debris flows. DeGraff et al. (2015) highlighted the variability of debris-flow initiating events relative to fire ignitions within broad geographic areas termed rainfall regimes by Moody and Martin (2009).

Whereas these rainfall regime areas provide emergency-response personnel and land managers with a general timing of anticipated debris flow hazard, DeGraff et al. (2015) demonstrated that $85 \%$ of post-fire debris flows take place with the first 12 months following the fire, with $71 \%$ occurring within the first 6 months. Only $7 \%$ of the debris flows following a fire occurred 1 and 1.5 years later generally when a second rainy season impacted the burned area. These results confirm the general rule of greater debris-flow hazard during the first 2 years following a fire as postulated by Cannon et al. (2011) and reflected in the reported occurrence of post-fire sedimentation in southern California (Santi and Morandi, 2013). Emergency-response personnel and land managers are increasingly aware of the immediate need to quickly institute appropriate mitigation measures to protect lives and property at risk from post-fire debris flows (DeGraff 1994; Prochaska et al., 2008; Lancaster et al., 2014; McCoy et al., 2016).

\section{Debris flow timing and vegetation communities}

DeGraff et al. (2015) found both non-forested and forested vegetation communities tend to experience an immediate increase in susceptibility to debris-flow occurrence in drainage basins recently burned by wildfires. With very few exceptions, the debris flows taking place during this period initiate through progressive entrainment of material eroded from hillslopes and channels by surface runoff (Parise and Cannon, 2012; DeGraff et al., 2015). The initiation of debris flows predominately by progressive entrainment of surficial and channel material has been observed in the field (DeGraff et al., 2011) and quantified in southern California (Santi et al., 2008).
In contrast to the 2 year post-fire immediacy of debris flow occurrence within all vegetative communities, DeGraff et al. (2015) identified a later period of increased debris flow susceptibility between 2.2 and 10 years after fires which occurred almost exclusively in forested areas. This additional period of increased post-fire debris flow susceptibility is attributable to infiltration-triggered debris flows where an initial shallow landslide rapidly transforms into a debris flow (Parise and Cannon, 2012). Studies by Meyer et al. (2001) and Wondzell and King (2003) of post-fire debris flows and related sedimentation in forested landscapes in Idaho and the Pacific Northwest provided early evidence for this later period when infiltration-triggered debris flows would be initiated from burned areas. This susceptibility was concluded to arise "several or more years..." after wildfire on forested slopes in Idaho (Meyer et al., 2001). Similarly, Wondzell and King (2003) found debris-slide initiated debris flows following wildfires in the Pacific Northwest occurring 5 to 10 years after a fire happened. Both studies saw the later period of post-fire debris flow occurrence as linked to the decay of tree roots in burned, forested drainage basins.

In this paper, we will examine why debris flows in burned, forested drainage basins revert from initiation by progressive entrainment immediately after a wildfire to many years later being infiltration-triggered. This exploration looks at a timber harvest practice which seems an analog to explain why this change in debris flow initiation takes place. Two case studies from wildfires on national forests in the Sierra Nevada in east-central California are presented to clarify the threat posed by the second, later susceptibility to post-fire debris flows in forested terrain and examine the implications for debris flow mitigation (Fig. 1). The first case study of the Pilot Ridge debris flow considers the factors resulting in this event and illustrates the hazard posed even in a sparsely inhabited area. The Pilot Ridge debris flow also illustrates how damage can take place within the source area, transport zone, and deposition zone of a debris flow (Hungr et al., 1987). The Big Creek restoration project case study suggests prioritized reforestation is a mitigation measure to counter this later post-fire debris flow hazard and demonstrates its application to a burned area.

\section{A rationale for effective post-fire debris flow mitigation in a forested terrain}

Tree roots - Using clearcutting as an analog for wildfire A well-developed body of research documents the importance of roots to slope stability (Sidle et al., 1985, Greenway, 1987, and Sidle and Ochiai 2006). The roots of woody plants, primarily trees, provide reinforcement and increase the inherent shear strength of soils mantling steep slopes. Gray and Megahan (1981) referred to this reinforcement in terms of the roots providing a pseudo-cohesion to the soil 


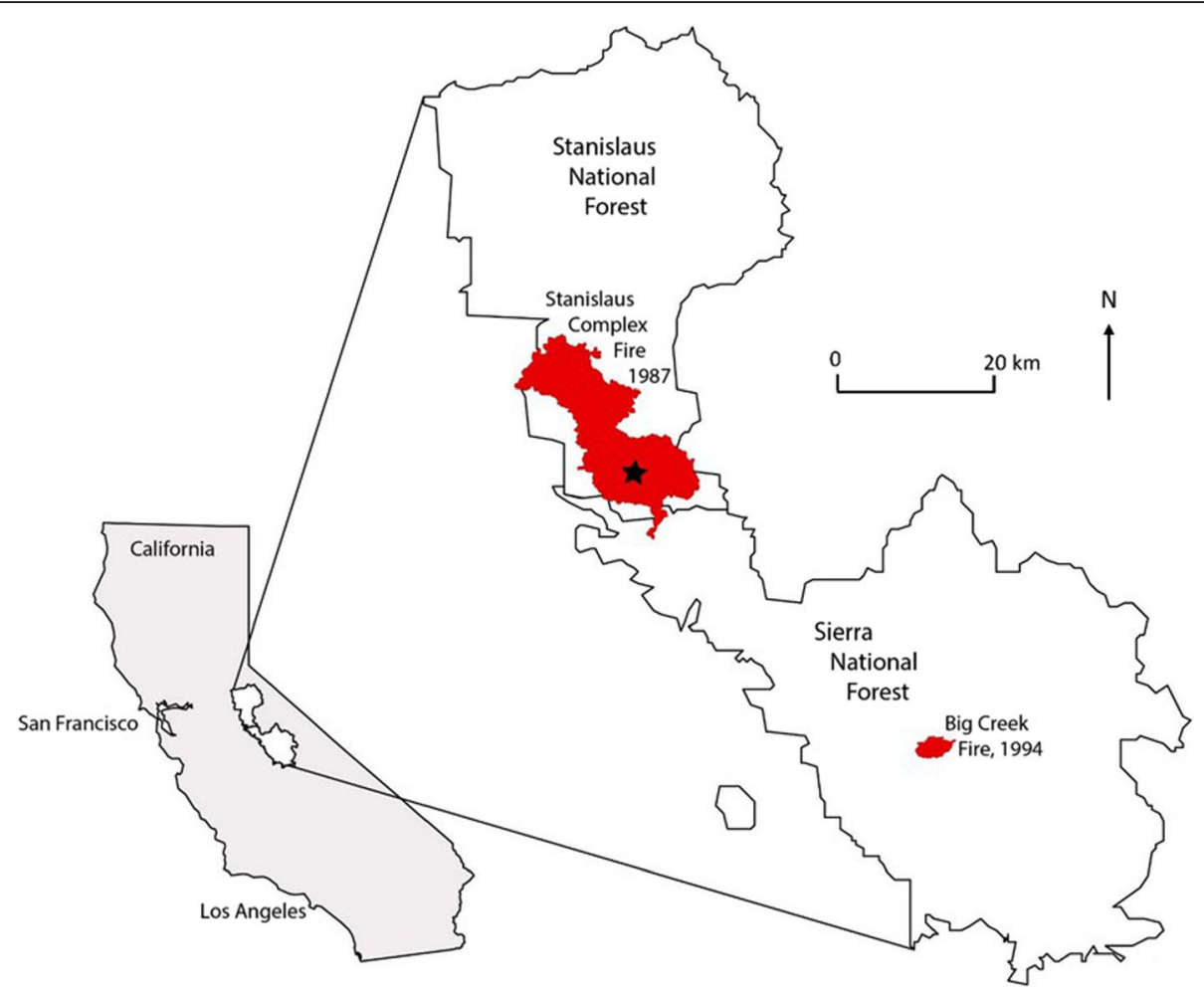

Fig. 1 Location map showing the area of the 1987 Stanislaus Complex Fire (red). The black star within the red area shows where the later Pilot Ridge debris flow occurred. The smaller red area is represents the fire-affected area of the 1994 Big Creek Fire. Both wildfires affected forested terrain within designated national forests

mass. At the time, research to understand the slope stabilizing role of roots was largely focused on their relationship to various timber harvest practices (Burroughs and Thomas, 1977; O'Loughlin and Zeimer, 1982; Watson et al., 1999; Sidle and Dhakal, 2003).

The timber harvest practice of particular interest to researchers during the 1970s and 1980s was clearcutting. Clearcutting was commonly applied to steep slopes and involved the removal of all trees over an area that might range from 4 to 16 ha in size. This harvest practice could be considered analogous to the effect of wildfire on forested drainage basins in terms of its influence on shallow landslides resulting in debris flow occurrence (Benda and Dunne, 1997).

In general, the loss of root strength through decay after timber harvest is a specific curve representing decay over time. The measured decline in root strength due to decay is very rapid in the first year but slows by the fourth year. However, the curves representing declining root strength vary according to the tree species and the site conditions where the trees grow (Burroughs and Thomas, 1977; O'Loughlin and Zeimer, 1982; Sidle and Dhakal, 2003; Wondzell and King, 2003). It is important to remember that any curve representing change in root strength can only show the time period when an initiating precipitation event has a greater chance of triggering an infiltration-triggered debris flow rather than implying a specific time for the occurrence of a debris flow (see Fig. 3.17 in Sidle and Ochiai, 2006).

An increased potential for infiltration-induced debris flows in burned drainage basins will depend on the extent the forest cover is affected by the wildfire. In a manner similar to a clearcut harvest unit, root decay begins in the weeks after burned trees are consumed by the wildfire. Because many other trees appear alive but are killed by the heating effect of the wildfire, their root decay is delayed. Fire-killed trees begin having decreasing root strength a year or two after the fire (Regelbrugge and Conard, 1993). The loss of trees will differ among the affected drainage basins within the wildfire perimeter because burning produces a mosaic ranging from unburned to completely burned areas. Only some drainage basins will have all or the majority of trees burned or significant heat injury resulting in tree mortality.

Declining root strength in fire-killed trees has an additional complication when trying to estimate the future time of greater susceptibility from infiltration-triggered debris flows. Jackson and Roering (2009) investigating three burned areas in the Oregon Coast Range found a more rapid strength decline in tree roots than anticipated from timber-harvest related studies. They suggested that fire may have an accelerating effect on the decline in root 
strength compared to timber harvest. Consequently, the specific point where loss of root strength is sufficient to favor debris flow occurrence can vary greatly within a given wildfire and between forested terrains in different geographic areas. This makes post-fire debris flow initiation in forested landscapes difficult to predict with any accuracy.

\section{Pilot ridge debris flow - Hazard in a burned, forested terrain}

The Stanislaus Complex wildfire and the subsequent Pilot Ridge debris flow is representative of a later post-wildfire debris flow occurrence in a forested terrain (DeGraff et al., 2015). On August 29, 1987, thousands of lightning strikes occurred and triggered many fires in the Sierra Nevada and northern mountain ranges of California (DeGraff and Lewis, 1989). Several wildfires on the Stanislaus National Forest south of Sonora, California in the vicinity of the Tuolumne River eventually formed the Stanislaus Complex wildfire (Fig. 1). Over the following weeks, this wildfire burned nearly 60,000 ha (Regelbrugge and Conard, 1993). Much of the burned area was a mixed conifer forest dominated by ponderosa pine. Trees were killed in forested drainage basins both by being consumed by fire or by heat injury causing mortality within one to 2 years after a wildfire (Regelbrugge and Conard, 1993). For the first few years after the wildfire, salvage logging was carried out in selected locations.

The 1997 New Year's Day storm event is known to have triggered only a few debris flows in the southern Sierra Nevada (DeGraff, 2001). One, known as the Pilot Ridge debris flow, occurred during the 30 minutes prior to 1:00 PM on January 2, 1997 (DeGraff, 1997) (Fig. 2). The time of occurrence is based on observations for the period just prior to and immediately after the flow occurred as reported by Forest Service personnel driving through the area, the Cal Trans crew called to clear Highway 120, and the local resident whose structures were affected. The nearest reporting stations in the vicinity of the debris flow occurrence only provide total daily precipitation. These stations, Sonora RS and Hetch Hetchy, reported cumulative total precipitation during the seven days prior to the debris flow of 150 and $190 \mathrm{~mm}$, respectively. On the day the debris flow occurred, additional precipitation of 53 and $73 \mathrm{~mm}$ was recorded.

The upper part of the north-facing drainage basin where the Pilot Ridge debris flow initiated was within the area burned by the 1987 Stanislaus Complex Wildfire. A little more than 9 years had passed since Pilot Ridge was burned during the Stanislaus Complex Fire. No reforestation had occurred within the burned drainage basin where the debris flow occurred. The top of the ridge is metamorphic bedrock of the Calaveras and Shoofly complexes with granitic bedrock underlying the remainder of the burned basin. The
Pilot Ridge debris flow initiated from two locations about $180 \mathrm{~m}$ apart at the bifurcated headwaters channel for this small drainage basin (DeGraff, 1997) (Fig. 2). Both locations showed field evidence of near simultaneous debris slide movement from the two source areas which then quickly coalesced into a single channelized debris flow mass.

The field evidence supports this debris flow being the result of infiltration-induced landslides rather than progressive entrainment of eroded material. The westernmost and larger of the initiating landslides left a semi-circular scar on the $55 \%$ slope which was $16 \mathrm{~m}$ across and about $18 \mathrm{~m}$ long parallel to the axis of movement (Figs. 2 and 3). The average depth to the slide plane was a little more than a meter. Even 26 days later, water was seeping from several points at the base of the headscarp and from within the upper scar area. The other initiating landslide to the east was smaller (Fig. 2). It was on a $60 \%$ slope but left a more elongate scar than the other landslide. While being about $18 \mathrm{~m}$ long parallel to the axis of movement like the larger landslide scar, it was only 6 to $7 \mathrm{~m}$ wide a with an average depth to the slide plane of about a meter.

Observed in the slide planes and scarps defining both landslide scars were sheared roots. The author has examined a number of other debris flows initiated by infiltration-triggered landslides and debris flows in unburned watersheds in the southern Sierra Nevada (DeGraff, 1994). Commonly, there are numerous roots dangling within the exposed slide plane and its margins where initial movement of the slide occurred. These are remnants of roots placed in tension during initial landslide movement before being snapped off by the moving mass. The root remnants within the slide plane are typically flexible and can be up to $60 \mathrm{~cm}$ long. Similar observations of roots within scars of infiltration-initiated landslides were made on forested slopes within the Oregon Coast Range (Schmidt et al., 2001). In contrast, the roots exposed in both landslide scars at Pilot Ridge were commonly sheared close to or at the slide plane (Fig. 4a). They were also noticeably dry and brittle (Fig. 4b).

From the source areas, the debris flow travelled nearly one kilometer over a vertical drop of about $240 \mathrm{~m}$. It flowed at a velocity of 8 to nearly $10 \mathrm{~km}$ per hour down the existing channel of an unnamed tributary to the South Fork Tuolumne River. Velocity was determined from field measurements applied to two different methods (Costa, 1984; Webb et al., 1988). The maximum velocity measured for the Pilot Ridge debris flow was about half the average for other debris flows in the Sierra Nevada (DeGraff, 1994). Along its flow path, the debris flow plugged the culvert at Forest Road 1S66 and surged across the road leaving debris and eroding its downslope embankment (Figs. 2 and 5). The flow continued down channel to plug another culvert and leave a significant deposit covering Forest Road $1 \mathrm{~S} 13$ as it continued 


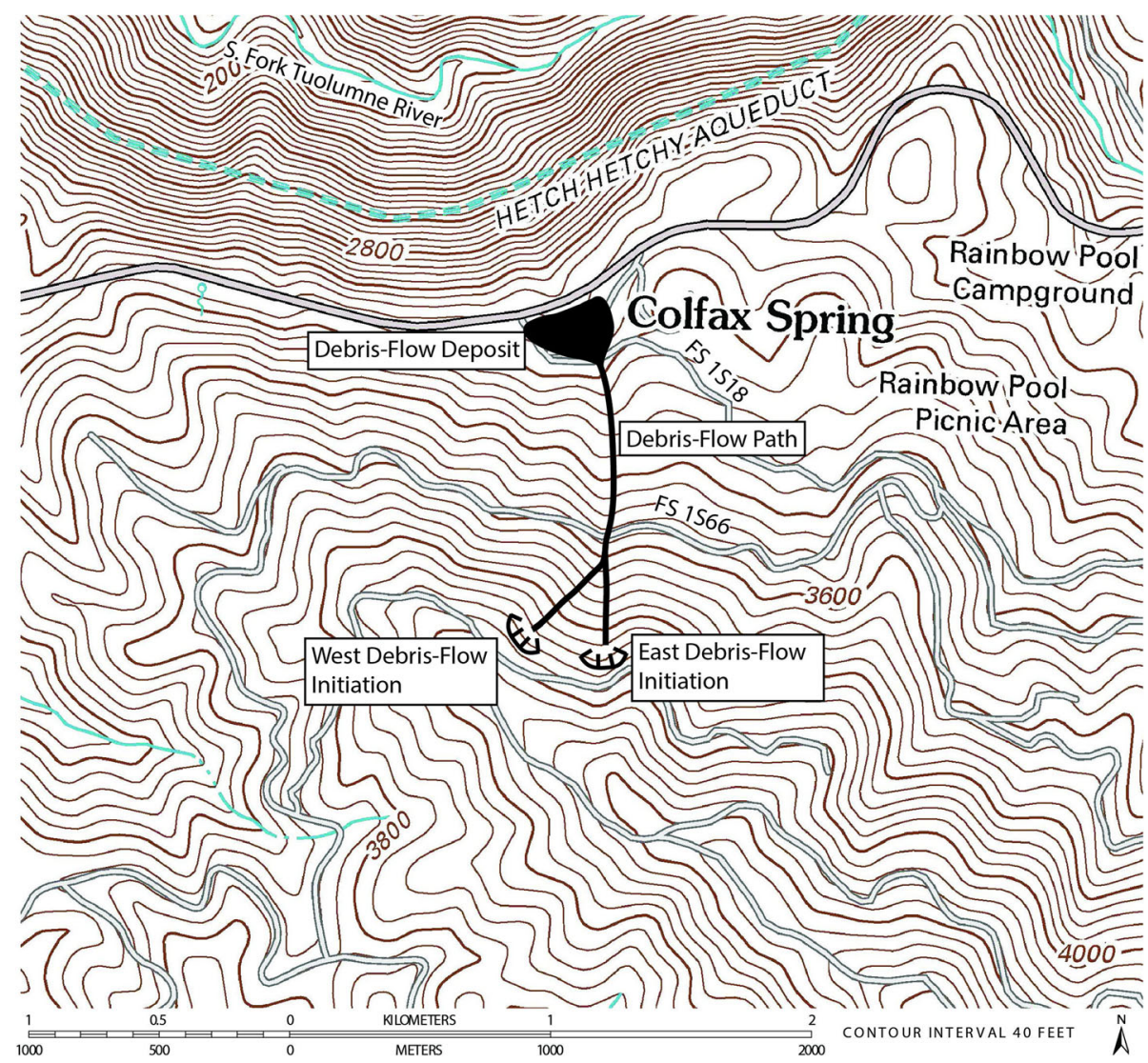

Fig. 2 A detailed map for the area affected by the Pilot Ridge debris flow in 1997. The deposition area covers the location of the house and outbuilding affected by the debris flow. The east-west highway adjacent to the highway is U.S. Highway 120 which provides access to Yosemite National Park to the east of this location

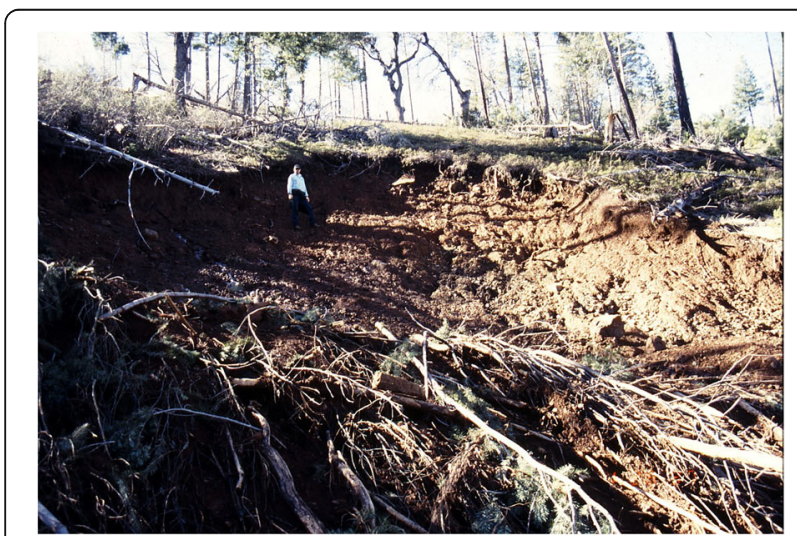

Fig. 3 The west debris flow initiation area of the Pilot Ridge debris flow. This was the larger of the two initiating debris slides. A 6-ft tall individual provides scale. Fallen fire-killed trees are seen around this area. Water was still flowing from the slide scarp to the lower left of the individual across to narrowly miss a residence and inundate an area around a detached building before finally coming to rest in a deposit on Forest Road 1S13 and California Highway 120 (DeGraff, 1997; Fig. 2).

Based on the field evidence, the infiltration-initiated landslides responsible for the Pilot Ridge debris flow are attributable to decreased soil strength from root decay of fire-killed trees. The significant $1997 \mathrm{New}$ Year's Day storm event served as the trigger for initiating the debris slides within the weakened soil mass. The Pilot Ridge debris flow represents a later post-fire debris flow occurrence in a forested terrain and its destructive effects demonstrate the need for mitigation.

\section{Rapid reforestation as an effective post-fire debris flow mitigation measure}

Unlike for debris flows occurring immediately following wildfires, there are no specific models for predicting size, probability of occurrence, or runout for the post-fire debris flows resulting from the later period of infiltration-triggered debris slides within forested watersheds. A conceptual model of relative root reinforcement after clearcut harvest can provide some valuable insight in this 

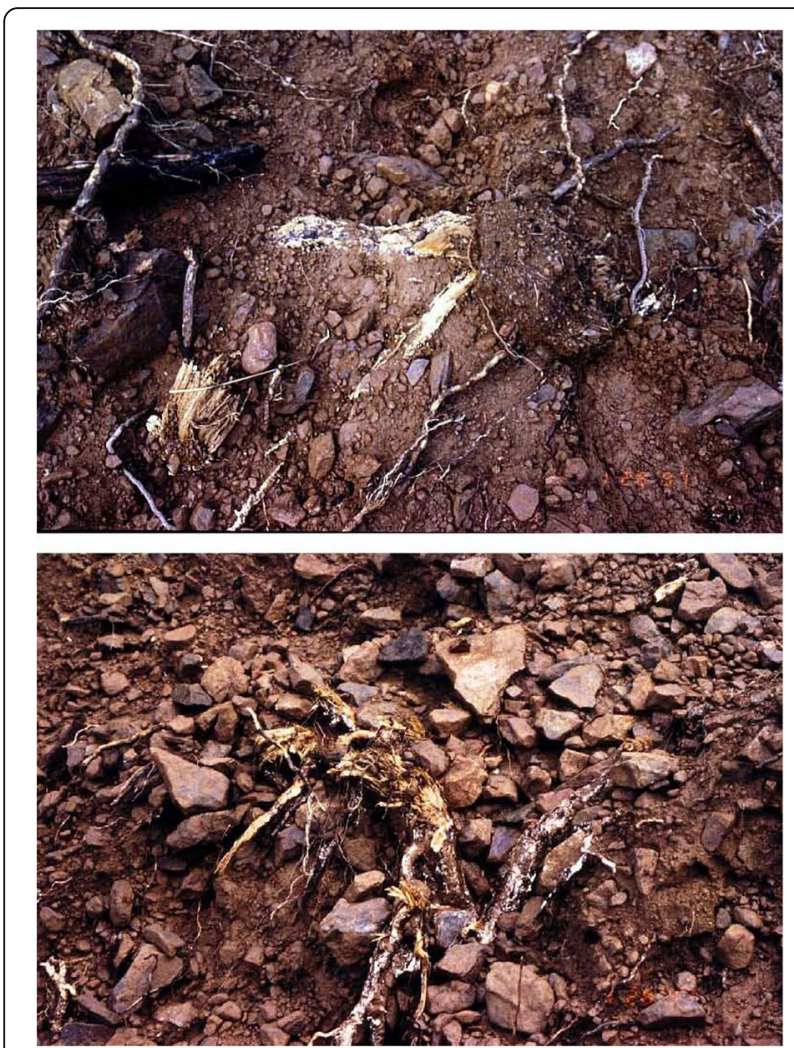

Fig. 4 Two close up views of roots exposed in the east slide plane where the Pilot Ridge debris flow initiated. These brittle, sheared exposed roots were widely spread across both east and west initiation areas

regard (Zeimer, 1981). This model compares curves representing relative root reinforcement for a forested slope that was clearcut. The salient curve represents the net reinforcement of the soil by roots over time (see Fig. 1a in Zeimer, 1981). The curve is the sum of residual reinforcement from decaying roots and reinforcement

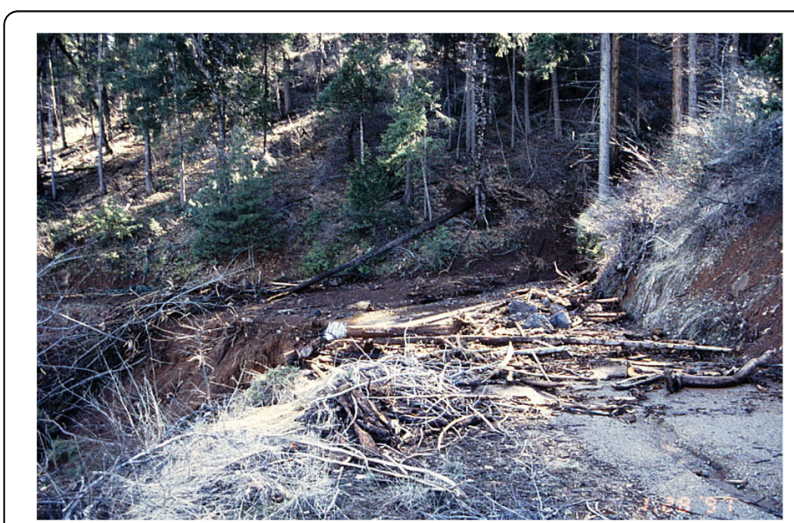

Fig. 5 The flow path of the Pilot Ridge debris flow where it crossed Forest Road 1S66. Note the levees of soil and transported trees left on the road and the undermining of the roadbed by the debris flow's passage from new roots as the forest regenerates. Because this is a hypothetical curve, we can only draw inferences which seem important to post-fire infiltration-triggered debris flow occurrence (Zeimer, 1981). The soil is at its weakest shear strength when the net root reinforcement is at its lowest point (smallest sum of reinforcement by decaying tree roots and reinforcement by roots of regrowing trees). For a specific burned area, data on the decay for the burned forest vegetation type and on the forest vegetation type regrowing due to existing seed within the soil or from replanting with seedlings could be used to develop an actual model showing the time when post-fire debris flow susceptibility is greatest, i.e., net root strength is at its lowest. What seems to be a more important implication of Ziemer's conceptual model is that a delay in reforestation of only 5 years results in a significantly lower net reinforcement compared to prompt reforestation. From this conceptual model, it is suggested that mitigation of infiltration-triggered debris flows during the later post-fire susceptibility period could be accomplished through rapid reforestation. Given the trend for very large fires, rapid reforestation could be applied selectively to drainage basins with residences, infrastructure or other high value features down channel.

The Big Creek wildfire in August 1994 burned approximately 2277 ha within the Sierra National in the central Sierra Nevada of California just south of the Stanislaus National Forest (Fig. 1). About 35\% of the burned area had either moderate or high burn severity (Sierra NF, 1995). Burn severity is a measure reflecting the combined effect from loss of vegetation and heating impact to the near-surface soil (Parsons et al., 2010). Debris flow potential immediately following the wildfire focused on the threat to the major hydroelectric facilities operated by Southern California Edison Company further downstream in Big Creek. The threat to the community of Big Creek and both County and Forest Service roads was another concern. Operational changes to protect the hydroelectric generating equipment along with installing various debris catchment devices above the community were undertaken to mitigate the potential risk due to immediate debris flow occurrence.

In fall 1994, planning was started for the Big Creek Ecological Recovery Project (Sierra NF, 1995). This vegetation management effort included extensive planting for reforestation. Among the planning objectives was minimizing the later debris flow threat to the community of Big Creek and critical infrastructure including a major Forest Service road and a Fresno county road. Areas posing this later threat were identified based on a forest-wide inventory of landslides and local area experience with infiltration-initiated debris flows in previous years (DeGraff et al., 1984; DeGraff, 1994). A total of 500 ha were identified where debris flow-prone slopes 
coincided with moderate to high tree mortality. The mortality represented where trees were consumed by the wildfire or were identified by ground survey as expected to die due to excessive heat injury. The identified areas represented potential source areas for fire-related later infiltration-type debris flows could occur in the future.

Based on Zeimer's (1981) conceptual model, fostering growth of any surviving trees and reforestation to replace those lost or dying was proposed for the 500 ha identified as debris flow-prone (Sierra NF, 1995). Priority was given for reforestation on 441 ha upslope from Stump Springs Road, a major Forest Service road, crossing the burned area that had experienced significant debris flow damage in 1982 and 1983 (DeGraff et al., 1984). Reforestation, concentrated in areas where mixed conifer species had grown, began in the spring of 1995 with the remainder being planted in spring 1996.

No debris flows from upslope initiation sites impacted Stumps Springs Road or other connecting roads within the burned watersheds during the subsequent 17 years (1996-2013). This was based on observations made during normal seasonal and post-storm event maintenance patrols to identify road damage occurrence. Late spring storms capable of triggering infiltration-type debris flows did occur in this part of the Sierra Nevada, notably in 2010 when a number of debris flows were triggered about $35 \mathrm{~km}$ south of the Big Creek Fire area. So the observed absence of debris flows within the areas made more susceptible by the Big Creek Fire is consistent with the expected debris flow activity where the reforestation mitigation measure was implemented. However, it is not possible to determine if the absence of infiltration-initiated debris flows within the 441-ha reforested areas was due to the reforestation mitigation measure or a lack of rainfall or snowmelt-triggering conditions affecting the burned area. We can only establish that infiltration-type debris flows were not observed within the area burned by the Big Creek Fire during the period when a burned, forested area has an increased susceptibility due to root decay. After 17 years, any future infiltration-type debris flows from this burned area are less likely to be a consequence of the wildfire effects or mitigation measure and more likely to represent natural recovery to pre-fire debris flow susceptibility levels (DeGraff et al., 1984, DeGraff, 1994).

\section{Discussion and conclusions}

Understanding the timing of debris flows following wildfire has implications for successful protection of life and property. The attention and research devoted to the debris flows occurring in the few months to first year following a wildfire is well placed. The threat is widespread and largely independent of the type of vegetative community burned. The immediacy of this threat calls for prompt implementation of mitigation measures. The design and placement of these measures needs to be effective for debris flows resulting from progressive entrainment of material eroded from hillslopes and channels by surface runoff. Increasingly fine-tuned models for probable debris flow occurrence, expected volume, and runout area facilitate undertaking effective mitigation even for very large fires. Rapidly locating where mitigation measures are needed makes implementation possible when only months may exist before the first triggering storm event. Additionally, the models provide data on the storm used in their development which can be incorporated into the design of a mitigation measure such as emergency evacuation.

When wildfire burns a forested area, the mitigation of any imminent debris flow threat must also be coupled with similarly prompt action to limit the impact of later debris flows. Some post-fire debris flow mitigation measures, such as debris basins and deflection berms installed to protect life and property threatened by the debris flow hazard immediately after the wildfire, should be maintained within forested drainage basins as additional protection from the later infiltration-triggered debris flows.

The later debris flow threat in burned forest areas provides an opportunity for mitigation within the debris flow source area. This mitigation measure, reforestation, is a common activity applied to restore a forest following a wildfire and can be applied to source areas. Because the later threat of debris flows in forested drainage basins is associated with infiltration-triggered landslides, there is sufficient time to prioritize reforestation within basins where: 1) the soil burn severity is high, 2) post-fire tree mortality is greater, and 3) past infiltration-induced landslide activity is concentrated. Countering the decreasing soil shear strength resulting from root decay of fire-killed trees with the increasing root strength of growing replanted trees is optimal when implemented within 1 to 2 years after the wildfire.

Implementing reforestation in a timely manner as a mitigation measure after a wildfire is only a means to avoid infiltration-type debris flows due to increased susceptibility attributable to fire. The natural, or pre-fire, susceptibility to infiltration-initiated debris flows within a forested terrain will exist in the future because this mitigation measure only returns the forest to a pre-fire susceptibility level. Therefore, any future studies of the effectiveness of this mitigation measure will need a basis for discriminating whether later infiltration-type debris flows are a consequence of changes attributable to the wildfire or to those other conditions influencing susceptibility of such debris flows.

\section{Funding}

No financial support was provided other than salary during employment and personal resources during retirement. The technical scope, methods, and data collection were authorized to be determined by the author. The funding entity only required conclusions and documentation of findings in internal documents. 


\section{Availability of data and materials}

Data sharing not applicable to this article as no datasets were generated or analyzed during the current study.

\section{Authors' contributions}

As noted above, all work including manuscript preparation was carried out by the author. The author read and approved the final manuscript.

\section{Authors' information}

1981 and 2013, the author served as geologist or team leader on 36 Burned Area Emergency Response teams conducting field assessment of post-fire impacts from wildfires primarily in California. His primary responsibility was the identification of landslide/debris flow hazard threats resulting from the wildfire, proposing technical measures to limit that hazard, and development of cost and design criteria for their implementation. In some instances, he was project leader for implementing mitigation measures following the wildfire. To improve carrying out these responsibilities, the author collaborated with researchers in other Federal and State agencies to improve his skills in effectively undertaking these duties. Consequently, he continues to maintain an interest in the developing understanding of this hazard.

\section{Competing interests}

The data and analyses serving as the basis of this manuscript were all carried out by the author in the course of his work duties as a geologist for the USDA Forest Service. The compilation and interpretations provided are those of the author under his own direction during retirement.

\section{Publisher's Note}

Springer Nature remains neutral with regard to jurisdictional claims in published maps and institutional affiliations.

\section{Received: 7 March 2018 Accepted: 30 April 2018}

\section{Published online: 25 May 2018}

\section{References}

Abatzoglou, J.T., and A.P. Williams. 2016. Impact of anthropogenic climate change on wildfire across western US forests. Proceedings of the National Academy of Sciences 113 (42): 11770-11775

Barbero, R., J.T. Abatzoglou, N.K. Larkin, C.A. Kolden, and B. Stocks. 2015. Climate change presents increased potential for very large fires in contiguous United States. International Journal of Wildland Fire 24: 892-899.

Benda, L., and T. Dunne. 1997. Stochastic forcing of sediment supply to channel networks from landsliding and debris flow. Water Resources Research 33 (12): 2849-2863.

Burroughs, E.R., and B.R. Thomas. 1977. Declining root strength in Douglas-fir after felling as a factor in slope stability. Research paper INT-190, 27. Utah: USDA Forest Service Ogden.

Cannon, S.H. 2001. Debris-flow generation from recently burned watersheds. Environmental \& Engineering Geoscience 7 (4): 321-341.

Cannon, S.H., E.M. Boldt, J.L. Laber, J.W. Kean, and D.M. Staley. 2011. Rainfall intensity-duration thresholds for postfire debris-flow emergency-response planning. Natural Hazards 59: 209-236.

Cannon, S.H., and J.V. DeGraff. 2009. Incorporating spatial, temporal, and climate variability into tools for assessing post wildfire debris-flow hazards. In Landslides: Disaster Risk Reduction, ed. K. Sassa and P. Canuti, 177-190. Berlin: Springer-Verlag.

Cannon, S.H., J.E. Gartner, R.C. Wilson, J.C. Bowers, and J.L. Laber. 2008. Storm rainfall conditions for flood and debris flows from recently burned areas in southwestern Colorado and southern California. Geomorphology 96: 250-269.

Cannon, S.H., R.M. Kirkham, and M. Parise. 2001. Wildfire-related debris-flow initiation processes, storm King Mountain, Colorado. Geomorphology 39: 171-188.

Cannon, S.H., and S.L. Reneau. 2000. Conditions for generation of fire-related debris flows, Capulin canyon, New Mexico. Earth Surface Processes and Landforms 25: 1103-1121.

Costa, J.E. 1984. Physical geomorphology of debris flows. In Developments and applications of geomorphology, ed. J.E. Costa and P.J. Fleischer, 268-317. Berlin: Springer-Verlag.

DeGraff, J.V. 1994. The geomorphology of some debris flows in the southern sierra Nevada, California. Geomorphology 10: 231-252.

DeGraff, J.V. 1997. Geologic investigation of the pilot ridge debris flow, Groveland Ranger District, Stanislaus National Forest, 20. Sonora, CA: USDA Forest Service.
DeGraff, J.V. 2001. Sourgrass debris flow: A landslide triggered in the sierra Nevada by the January 1997 new year storm. In Engineering geology practice in northern California, ed. H. Ferriz and R. Anderson, vol. 210, 69-76. California: div. Of mines and geology bulletin.

DeGraff, J.V. 2014. Improvement in quantifying debris flow risk for post-wildfire emergency response. Geoenvironmental Disasters 1: 5. https://doi.org/10. 1186/s40677-014-0005-2.

DeGraff, J.V., S.H. Cannon, and A.J. Gallegos. 2007. Reducing post-wildfire debris flow risk through the burned area emergency response (BAER) process. In Conference presentations, $1^{\text {st }}$ north American landslide conference, ed. V.R. Schaefer, R.L. Schuster, and A.K. Turner, Special Publication No. 23, 14401447. Vail: AEG Special Publication No.

DeGraff, J.V., S.H. Cannon, and J.E. Gartner. 2015. The timing of susceptibility to post-fire debris flows in western United States. Environmental \& Engineering Geoscience 21 (4): 277-292.

DeGraff, J.V., and D.S. Lewis. 1989. Using past landslide activity to guide postwildfire mitigation. In Engineering geology and geotechnical engineering, ed. R. J. Watters, 65-75. Rotterdam: A. A. Balkema.

DeGraff, J.V., J. McKean, P.E. Watanabe, and W.F. McCaffery. 1984. Landslide activity and groundwater conditions: Insights from a road in the central sierra Nevada. Vol. 965, 32-37. California: Transportation Research Record.

DeGraff JV, Wagner D, Gallegos AJ, DeRose M, Shannon C, Ellsworth T (2011) The remarkable occurrence of large rainfall-induced debris flows at two different locations on July 12, 2008, sierra Nevada, CA. Landslides 8(2):

DeGraff, Jerome V., Susan H. Cannon, and Mario Parise. 2013. Limiting the immediate and subsequent hazards associated with wildfires. In Landslide science and practice (global environmental change), ed. C. Margottini, P. Canuti, and K. Sassa, vol. 4, 199-209. Berlin: Springer-Verlag, Vol.

Giraud, R.E., and G.N. McDonald. 2007. the 2000-2004 fire-related debris flows in northern Utah. In proceedings of the $1^{\text {st }}$ north American landslide conference, ed. V.R. Schafer, R.L. Schuster, and A.K. Turner, Special Publication No. 23, 1522-1531. Vail: AEG sp publication.

Gray, D.H., and W.F. Megahan. 1981. Forest vegetation removal and slope stability in the Idaho Batholith. USDA Forest Service Research Paper INT-271, 23. Ogden, Utah: Intermountain forest and Range Experiment Station.

Greenway, D.R. 1987. Vegetation and slope stability. In Slope stability, geotechnical engineering and geomorphology, ed. M.G. Anderson and K.S. Richards, 187230. Chicester: John Wiley \& Sons.

Hungr, O. 2005. Classification and terminology. In Debris-flow hazards and related phenomena, ed. M. Jakob and O. Hungr, 9-23. Berlin: Springer.

Hungr, O., G.C. Morgan, D.F. VanDine, and D.R. Lister. 1987. Debris flow defenses in British Columbia. In Debris Flows/Avalanches: Process, Recognition, and Mitigation, Reviews in Engineering Geology, ed. J.E. Costa and G.F. Wieczorek, vol. 7, 201-222. Boulder, CO: Geological Society of America.

Jackson, M., and J.J. Roering. 2009. Post-fire geomorphic response in steep, forested landscapes: Oregon coast range, USA. Quaternary Science Reviews 28 (11-12): 1131-1146.

Jordan, P., and S.A. Covert. 2009. Debris flows and floods following the 2003 wildfires in southern British Columbia. Environmental \& Engineering Geoscience 15: 217-234

Keeley, J.E., and C.J. Fotheringham. 2001. Historic fire regime in southern California shrublands. Conservation Biology 15 (6): 1536-1548.

Lancaster, J.T. S.E. McCrea, and W.R. Short. 2014. Assessment of post-fire runoff hazards for pre-fire hazard mitigation planning - Southern California. California Geological Survey Special Report 234: 66.

McCoy, K., V. Krasko, P. Santi, D. Kaffine, and S. Rebennack. 2016. Minimizing economic impacts from post-fire debris flows in the western United States. Natural Hazards 83: 149-176.

Meyer, G.A., J.L. Pierce, S.H. Wood, and A.J.T. Jull. 2001. Fire, storms, and erosional events in the Idaho batholith. Hydrological Processes 15: 3025-3038.

Moody, J.A., and D.A. Martin. 2009. Synthesis of sediment yields after wildland fire in different rainfall regimes in the western United States. International Journal of Wildland Fire 18: 96-115.

O'Loughlin, C., and R.R. Zeimer. 1982. The importance of root strength and deterioration rates upon edaphic stability in steepland forests. In Carbon Uptake and Allocation in Subalpine Ecosystems as a Key to Management, 70-78. Corvallis, OR: Proceedings IUFRO Workshop.

Parise, M., and S.H. Cannon. 2012. Wildfire impacts on the processes that generate debris flows in burned watersheds. Natural Hazards 61: 217227 
Parsons, A., P.R. Robichaud, S.A. Lewis, C. Napper, and J.T. Clark. 2010. Field guide for mapping post-fire soil burn severity, 49. Fort Collins: US Forest Service General Technical Report RMRS-GTR-243.

Parsons, D.J., and S.H. DeBenedetti. 1979. Impact of fire suppression on a mixedconifer forest. Forest Ecology and Management 2: 21-33.

Prochaska, A., P.M. Santi, and J.D. Higgins. 2008. Debris basin and deflection berm design for fire-related debris-flow mitigation. Environmental \& Engineering Geoscience 24 (4): 297-313.

Radeloff, V.C., R.B. Hammer, S.I. Stewart, J.S. Fried, S.S. Holcomb, and J.F. McKeefry. 2005. The wildland-urban interface in the United States. Ecological Applications 15 (3): 799-805.

Regelbrugge, J.C., and S.G. Conard. 1993. Modeling tree mortality following wildfire in pinus ponderosa forests in the central sierra Nevada of California. International Journal of Wildland Fire 3 (3): 139-148.

Rengers, F.K., L.A. McGuire, J.A. Coe, J.W. Kean, R.L. Baum, D.M. Staley, and J.W. Godt. 2016. The influence of vegetation on debris-flow initiation during extreme rainfall in the northern Colorado front range. Geology 44 (10): 823-826.

Santi, P.M., V.G. de Wolfe, J.D. Higgins, S.H. Cannon, and J.E. Gartner. 2008 Sources of debris flow material in burned areas. Geomorphology 96: 310-321.

Santi, P.M., and L. Morandi. 2013. Comparison of debris-flow volumes from burned and unburned areas. Landslides 10 (6): 757-769.

Schmidt, K.M., J.J. Roering, J.D. Stock, W.E. Dietrich, D.R. Montgomery, and T. Schaub. 2001. The variability of root cohesion as an influence on shallow landslide susceptibility in the Oregon coast range. Canadian Geotechnical Journal 38: 995-1024.

Schultz, W.H., J.A. Coe, W.L. Ellis, and J.D. Kibler. 2006. Preliminary assessment of landslides along the Florida River downstream from lemon reservoir, La Plata County, 26. Colorado: Geological Survey Open-file Report 2006-1343.

Sidle, R.C., and A.S. Dhakal. 2003. Recent advances in the spatial and temporal modeling of shallow landslides. In Integrated Modelling of Biophysical, social and Economic Systems for Resource Management Solutions, Proc. MODSIM 2003, vol. 2, 602-607. Canberra: Modeling and Simulation Society of Australia and New Zealand.

Sidle, R.C., and H. Ochiai. 2006. Landslides Processes, Prediction, and Land Use. Water Resources Monograph. Vol. 18, 312. Washington, DC: American Geophysical Union.

Sidle, R.C., A.J. Pearce, and C.L. O'Loughlin. 1985. Hillslope stability and land use. Water Resources Monograph. Vol. 11, 140. Washington, DC: American Geophysical Union.

Sierra, N.F. 1995. Big creek ecological recovery project-environmental assessment, 101. Clovis, CA: USDA Forest Service.

Staley, D.M., J.A. Negri, J.W. Kean, J.L. Laber, A.C. Tillery, and A.M. Youberg. 2017. Prediction of spatially explicit rainfall intensity-duration thresholds for postfire debris-flow generation in the western United States. Geomorphology 278: 149-162.

Wagner, D.L., J.V. De Graff, and J.T. Lancaster. 2013. Debris flows in the southern and eastern sierra Nevada region, California. In Geologic excursions from Fresno, California, and the Central Valley: A tour of California's iconic geology, ed. K. Putirka, vol. 32, 99-128. Geological Society of America field guide. https://doi.org/10.1130/2013.0032(06).

Watson, A., C. Phillips, and M. Marden. 1999. Root strength, growth, and rates of decay: Root reinforcement changes of two tree species and their contribution to slope stability. Plant and Soil 217: 39-47.

Webb, R.H., P.T. Pringle, S.L. Reneau, and G.R. Rink. 1988. Monument Creek debris flow, 1984: Implication for formation of rapids on the Colorado River in grand canyon National Park. Geology 16: 50-54.

Westerling, A.L. 2016. Increasing western US forest wildfire activity: Sensitivity to changes in the timing of spring. Phil Trans R Soc B 371: 20150178 https://doi.org/10.1098/rstb.2015.0178.

Westerling, A.L., H.G. Hildalgo, D.R. Cayan, and T.W. Swetnam. 2006. Warming and earlier spring increase western U.S. forest wildfire activity. Science 313: 940-943.

Wondzell, S.M., and J.G. King. 2003. Postfire erosional processes in the Pacific northwest and rocky mountain regions. Forest Ecology and Management 178: 75-87.

Zeimer RR (1981) The role of vegetation in the stability of forested slopes. Proceedings XVII World Congress, International Union of Forestry Research Organizations p. 297-308.

\section{Submit your manuscript to a SpringerOpen ${ }^{\circ}$ journal and benefit from:}

- Convenient online submission

- Rigorous peer review

- Open access: articles freely available online

- High visibility within the field

- Retaining the copyright to your article

Submit your next manuscript at $\gg$ springeropen.com 